\title{
Pengaruh Kepuasan Kerja dan Beban Kerja Terhadap Kinerja Pegawai Pada Dinas Tenaga Kerja dan Transmigrasi Banyuasin
}

\author{
Totok Sudiyanto \\ Akuntansi, FE Universitas PGRI Palembang \\ totoktajir78@univpgri-palembang.ic.id
}

\begin{abstract}
ABSTRAK
Rumusan masalah dalam penelitian ini adalah adakah pengaruh kepuasan kerja dan beban kerja terhadap kinerja pegawai pada Dinas Tenaga Kerja dan Transmigrasi Banyuasin.Tujuannya adalah untuk mengetahui pengaruh pengaruh kepuasan kerja dan beban kerja secara bersama - sama terhadap kinerja pegawai pada Dinas Tenaga Kerja dan Transmigrasi Banyuasin. Penelitian ini termasuk jenis penelitian asosiatif. Data yang digunakan dalam penelitian ini adalah data primer. Teknik pengumpulan data yang digunakan berupa kuestioner. Metode analisis yang digunakan adalah metode kualitatif dan kuantitatif dengan alat analisis regresi linear berganda, uji normalitas, uji heterokedastisitas, uji multikolinearitas, uji korelasi, uji $F$, uji $t$, dan uji determinasi. Hasil analisis dengan regresi linear berganda yang peneliti lakukan pada variabel kepuasan kerja $(X 1)$ dan beban kerja (X2) terhadap Kinerja pegawai $(Y)$ dengan persamaan $Y=1,809+0,318 X_{1}+0,283 X_{2}+e$. Hasil penelitian juga menunjukkan bahwa secara simultan kepuasan kerja dan beban kerja berpengaruh positif terhadap kinerja pegawai Sedangkan secara parsial kepuasan kerja dan beban kerja berpengaruh positif terhadap kinerja pegawai pada Dinas Tenaga Kerja dan Transmigrasi Banyuasin.
\end{abstract}

Kata Kunci: Kepuasan Kerja, Beban Kerja Dan Kinerja Pegawai.

\begin{abstract}
The formulation of the problem in this study is whether there is an effect of job satisfaction and workload on employee performance at the Banyuasin Manpower and Transmigration Office. The aim is to determine the effect of job satisfaction and workload together on employee performance at the Banyuasin Manpower and Transmigration Office. This research is an associative research. The data used in this study are primary data. Data collection techniques used in the form of questionnaires. The analytical method used is qualitative and quantitative methods with multiple linear regression analysis tools, normality test, heterokedasticity test, multicollinearity test, correlation test, $F$ test, $t$ test, and determination test. The results of the analysis with multiple linear regression researchers conducted on the variable job satisfaction (X1) and workload $(X 2)$ on employee performance $(Y)$ with the equation $Y=1.809+0.318 X 1+0.283 X 2+e$. The results also showed that job satisfaction and workload simultaneously had a positive effect on employee performance. While job satisfaction and workload partially had a positive effect on employee performance at the Banyuasin Manpower and Transmigration Office.
\end{abstract}

Keywords: Job Satisfaction, Workload and Employee Performance.

\section{A. PENDAHULUAN}

Sumber daya manusia (SDM) mempunyai peranan penting dalam mewujudkan kepentingan perusahaan atau organisasi. Mengingat pentingnya sumber daya manusia dalam menentukan tingkat keberhasilan tidak dapat diabaikan karena sumber daya manusia merupakan aset perusahaan atau organisasi dalam menjalankan aktivitasnya akan selalu berhadapan degan sumber daya manusia yang dinamis dan memiliki kemampuan untuk berkembang agar mampu menghadapi persaingan.

Dalam menghadapi persaingan kita harus memiliki sumber daya manusia (SDM) yang dapat bersaing 
degan instansi lainnya, maka sumber daya manusianya harus memiliki prestasi yang baik. Pengelolaan terhadap sumber daya manusia merupakan hal yang penting dalam pencapaian tujuan perusahaan atau instansi, umumnya pimpinan instansi atau perusahaan mengharapkan kinerja yang baik dari masing-masing pegawai dalam mengerjakan tugastugas yang diberikan sebuah instansi.

Kepuasan kerja sangat diperlukan bagi seorang pegawai dalam melakukan tugas-tugasnya. Bagi pegawai yang memperoleh kepuasan kerja akan melakukan tugastugasnya dengan sebaik mungkin walaupun beban kerjanya cukup berat. Beban kerja yang cukup berat itu tidak akan terlalu dirasakan oleh pegawai bila mereka memperoleh kepuasan kerja yang memadai.

Menurut Sutrisno (2019:74). Kepuasan kerja adalah suatu sikap pegawai terhadap pekerjaan yang berhubungan dengan situasi kerja, kerja sama antar pegawai, imbalan yang diterima dalam kerja, dan hal-hal yang menyangkut faktor fisik dan psikologis.

Dari pendapat ini dapat disimpulkan bahwa kepuasan kerja merupakan sikap pegawai terhadap pekerjaannya yaitu perasaan senang atau perasaan tidak senang yang dialami pegawai, yang biasanya yang diantaranya didasarkan atas kepuasan kerja yang mereka terima. Semakin besar kepuasan kerja yang mereka terima atau yang mereka rasakan maka beban yang berat akan dirasakan lebih ringan dan pegawai akan menunjukan kinerja yang baik.

Untuk memenuhi kinerja yang baik, Dinas Tenaga Kerja dan Transmigrasi Banyuasin mengharapkan tenaga pegawainya bekerja secara optimal. Namun terkadang beban kerja yang dirasakan cukup berat seperti, harus kerja diluar jam kerja untuk nasabah dan menyelesaikan pekerjaan lainnya. Untuk itu organisasi perlu memperhatikan faktor-faktor yang terkait dengaan kepuasan kerja pegawai dan beban kerja pegawai.

\section{B. KAJIAN TEORI}

1) Kepuasan Kerja

$>$ Pengertian Kepuasan Kerja

Menurut Sutrisno (2019:74), Kepuasan kerja adalah suatu sikap pegawai terhadap pekerjaan yang berhubungan dengan situasi kerja, kerja sama antar pegawai, imbalan yang diterima dalam kerja, dan hal-hal yang menyangkut faktor fisik dan psikologis.

\section{Faktor - Faktor Yang Mempengaruhi Kepuasan Kerja} Menurut Sutrisno (2019:77), banyak faktor yang memengaruhi kepuasan kerja pegawai. Faktor-faktor itu sendiri dalam peranannya memberikan kepuasan kepada pegawai bergantung pada pribadi masing-masing pegawai. Faktor-faktor yang memberikan kepuasan adalah :

1. Faktor individual, meliputi umur, kesehatan watak, dan harapan.

2. Faktor sosial, meliputi hubungan kekeluargaan, pandangan pekerja, kebebasan berpolitik, dan hubungan kemasyarakatan.

3. Faktor utama dalam pekerjaan, meliputi upah, pengawasan, ketenteraman kerja, kondisi kerja, dan kesempatan untuk maju. Selain itu, juga penghargaan terhadap kecakapan, hubungan sosial di dalam pekerjaan, ketepatan dalam menyelesaikan konflik antar manusia, perasaan diperlakukan adil baik yang menyangkut pribadi maupun tugas. 


\section{Indikator Kepusan kerja}

Menurut Hasibuan (2017:105), indikator kepuasan kerja seorang pegawai dapat dilihat dari beberapa hal berikut :

1. Menyenangi pekerjaannya

Pegawai sadar arah yang ditujunya, punya alasan memilih tujuannya, dan mengerti cara dalam bekerja. Dengan kata lain, seorang pegawai menyenangi pekerjaannya karena ia bisah mengerjakannya dengan baik.

2. Mencintai pekerjaannya

Dalam hal ini pegawai tidak sekedar menyukai pekerjaannya tapi juga sadar bahwa pekerjaan tersebut sesuai dengan keinginannya.

3. Moral kerja positif

Ini merupakan kesepakatan batinnya yang muncul dari dalam diri seseorang atau organisasi untuk mencapai tujuan tertentu sesuai dengan mutu yang ditetapkan.

4. Disiplin kerja

Kondisi yang tercipta dan terbentuk melalui proses dari serangkaian perilaku yang menunjukan nilai-nilai ketaatan, kepatuhan, kesetiaan, keteraturan dan atau ketertiban.

5. Prestasi kerja

Hasil kerja yang dicapai seseorang dalam melaksanakan tugas - tugas yang dibebankan kepadanya yang didasarkan atas kecakapan kesungguhan serta waktu.

\section{2) Pengertian Beban Kerja}

Menurut Danang Sunyoto (2012:64), beban kerja adalah beban kerja yang terlalu banyak dapat menyebabkan ketegangan dalam diri seseorang sehingga menimbulkan stress. Hal ini bisa disebabkan oleh tingkat keahlian yang dituntut terlalu tinggi, kecepatan kerja mungkin terlalu tinggi, volume kerja mungkin terlalu banyak dan sebagainya.

\section{$>$ Faktor - Faktor Yang Mempengaruhi Beban Kerja \\ Menurut Soleman (2011:85)} secara umum hubungan antara beban dan kapasitas kerja dipengaruhi oleh berbagai faktor yang sangat kompleks, baik internal maupun faktor eksternal :

1. Faktor eksternal : beban yang berasal dari luar tubuh pekerja seperti :

a. Tugas (task). Meliputi tugas bersifat seperti stasiun kerja, tata ruang, tempat kerja, kondisi ruang kerja, kondisi lingkungan kerja, sikap kerja, cara angkut, beben kerja yang diangkut,

b. Organisasi kerja. Meliputi lamanya waktu bekerja, waktu istirahat, shift kerja, sistem kerja dan sebagainya.

c. Lingkungan kerja. Lingkungan kerja ini dapat memberikan beben tambahan yang meliputi, lingkungan kerja fisik, lingkungan kerja miniawi, lingkungan kerja bioligis dan lingkungan kerja psikologis.

2. Faktor internal

Faktor internal adalah faktor yang berasal dari dalam tubuh akibat dari reaksi beben kerja ekternal yang berpotensi sebagai stresor, meliputi faktor somatis (jenis kelamin, umur, ukuran tubuh, status gizi, kondisi kesehatan, dan sebagainya,) dan faktor psiksi (motivasi, persepsi, kepercayaan, keinginan, kepuasan, dan se bagainya).

\section{Indikator Beban Kerja}

Menurut Putra (2012:22), Indikator beban kerja meliputi :

1. Target Yang Harus Dicapai

Pandangan individu mengenai besarnya target kerja yang diberikan untuk menyelesaikan pekerjaannya, misalnya mendapatkan nasabah. Pandangan mengenai hasil kerja yang harus diselesaikan dalam jangka waktu tertentu. 
2. Kondisi Pekerjaan

Mencakup tentang bagaimana pandangan yang dimiliki oleh individu mengenai kondisi pekerjaannya, misalnya mengambil keputusan dengan cepat pada saat melayani nasabah, serta mengatasi kejadian yang tak terduga seperti harus bekerja diluar jam kerja untuk nasabah dan menyelesaikan pekerjaan lainnya.

3. Standar Pekerjaan

Kesan yang dimiliki oleh individu mengenai pekerjaannya, misalnya perasaan yang timbul mengenai beban kerja yang harus diselesaikan dalam jangka waktu tertentu.

\section{3) Pengertian kinerja}

Kinerja adalah merupakan hasil yang dicapai oleh seseorang karyawan dalam melakukan tugasnya sesuai tanggung jawab yang diberikan kepadanya.

Menurut Wibowo (2014:3), kinerja adalah merupakan implementasi dari rencana yang telah disusun tersebut implementasi kinerja dilakukan oleh sumber daya manusia yang memiliki kemampuan, kompetensi, motivasi, dan kepentingan.

Menurut Wibowo (2014:7), kinerja merupakan hasil pekerjaan yang mempunyai hubungan kuat dengan tujuan strategi organisasi, kepuasan konsumen, dan memberi kontribusi pada ekonomi.

Dari penelitian di atas dapat disimpulkan bahwa kinerja adalah hasil kerja yang dicapai oleh seseorang. Baik kuantitas maupun kualitas dalam suatu organisasi.

\section{$>\quad$ Tujuan penilaian kinerja}

$$
\text { Menurut Sedarmayanti }
$$

(2014:264), tujuan penilaian kinerja yaitu:

1. Membantu meningkatkan kinerja.
2. Menetapkan sasaran bagi kinerja perorangan.

3. Menilai kebutuhan pelatihan dan pengembangan.

4. Menyepakati rencana untuk pengembangan karyawan dimasa depan.

5. Menilai potensi di masa depan untuk kenaikan pangkat

\section{Manfaat penelitian kinerja}

Menurut sedarmayanti

(2014:264), menfaat penilaian kinerja, yaitu:

1. Meningkatan prestasi kerja

Dengan adanya penilaian, baik pimpinan maupun karyawan memperoleh umpan balik dan mereka dapat memperbaiki pekerjaan prestasinya.

2. Memberikan kesempatan kerja yang adil

Penilaian akurat dapat menjamin karyawan memperoleh kesempatan menempati sisi pekerjaan sesuai kemampuannya.

3. Kebutuhan pelatihan dan pengembangan

Melalui penilaian kinerja, terdeteksi karyawan yang kemampuannya rendah sehingga memungkinkan adanya program pelatihan untuk meningkatkan kemampuan mereka.

4. Penyesuaian kompensasi

Melalui penilaian, pimpinan dapat mengambil keputusan dalam menentukan perbaikan pemberian kompensasi dan sebagainya.

5. Keputusan promosi dan demosi

Hasil penilaian kerja dapat digunakan sebagai dasar pengambilan keputusan untuk mempromosikan atau mendemosikan karyawan.

\section{$>$ Pengukuran kinerja}

Menurut Wibowo (2014:155), pengukuran terhadap kinerja perlu di lakukan untuk mengetahui apakah 
selama pelaksanaan kinerja terdapat devisi dari rencana yang telah ditentukan pengukuran kinerja yang tepat dapat dilakukan dengan cara:

1. Memastikan bahwa persyaratan yang diinginkan pelanggan telah terpenuhi.

2. Mengusahakan standar kinerja untuk menciptakan perbandingan.

3. Mengusahakan jarak bagi orang memonitor tingkat kinerja.

4. Menetapkan arti penting masalah kualitas dan menentukan apa yang perlu diprioritaskan.

5. Menghindari konsekuensi dari rendahnya kualitas.

6. Mempertimbangkan penggunaan sumber daya.

\section{$>\quad$ Indikator kinerja}

Menurut Wibowo (2011:141), bahwa indikator-indikator kinerja karyawan adalah sebagai berikut:

1. Umpan balik

Indikator ini dapat membuka kesempatan bagi semua karyawan untuk memberikan umpan balik (feedback) kepada semua anggota perusahaan lainnya, sehingga dapaat diidentifikasi kinerja individu, depertemen, atau proses dalam perusahaan yang perlu ditingkatkan.

2. Absensi

Tingkat absensi merupakan penting bagi proses perencanaan kapasitas yang mengidentifikasikan keberadaan dan keahlian karyawan ketika dibutuhkan. Pengukuran absensi juga dapat mengtahui moral dan sikap karyawan dalam perusahaan.

3. Motivasi dan komitmen

Motivasi dan komitmen bekerja merupakan hal penting dalam memaksimalkan pencapaian potensi perusahaan atau organisasi komitmen dan motivasi karyawan merupakan kontribusi yang penting, dimana karyawan dapat meyakinkan perusahaan atau organisasi bahwa karyawan berusaha semaksimal mungkin di dalam beraktivitas bekerja bagi keuntungan perusahaan atau organisasi tersebut.

4. Produktivitas karyawan

Merupakan pengukuran kontribusi karyawan bagi perusahaan dan ukuran kaji banding yang mengidentifikasi efisien serta efektifitas perusahaan atau organisasi.

5. Kepuasan karyawan

$\begin{array}{llr}\text { Beberapa } & \text { hasil penilaian } \\ \text { menunjukkan } & \text { peningkatan } \\ \text { kepuasan } & \text { karyawan }\end{array}$
meningkatkan kepuasan pelanggan meningkatkan kepuasan pelanggan dan peningkatan keuntungan bagi perusahaan. 7 jam kerja lamanya jam kerja mempunyai pengaruh yang signifikan terhadap kepuasan karyawan. Jam kerja yang terlalu lama mempunyai pengaruh negativ terhadap kepuasan pegawai.

\section{METODE PENELITIAN}

Menurut Sugiyono (2018:2), metode penelitian pada dasarnya merupakan cara ilmiah untuk mendapatkan data dengan tujuan dan kegunaan tertentu.

Menurut Sugiyono (2018:8), metode penelitian kuantitatif dapat diartikan sebagai metode penelitian yang berlandaskan pada filsafat positivisme, digunakan untuk meneliti pada populasi atau sampel tertentu pengumpulan data menggunakan instrumen penelitian, analisa data bersifat kuantitatif/statistik, dengan tujuan untuk menguji hipotesis yang telah ditetapkan.

Dalam penelitian ini metode yang digunakan yaitu metode kuantitatif karena data penelitian berupa angkaangka dan analisa data bersifat statistik. 
1) Populasi Dan Sampel

$>$ Populasi

Menurut Sugiyono (2018:80), Populasi adalah wilayah generalisasi yang terdiri atas: obyek/subyek yang mempunyai kualitas dan karakteristik tertentu yang di tetapkan oleh peneliti untuk di pelajari dan kemudian di tarik kesimpulanya.

Populasi dalam penelitian ini adalah Pegawai Negri Sipil (PNS) yang ada di Dinas Tenaga Kerja dan Transmigrasi Banyuasin sebanyak 69 orang.

Sampel

Sampel adalah bagian dari jumlah dan karakteristik yang dimiliki oleh populasi (Sugiyono, 2018:81). Pengambilan sampel dalam penelitian ini dengan teknik probability sampling yaitu proportionate stratifed random sampling dengan menggunakan rumus slovin. Menurut Sugiyono (2018:81), probability sampling adalah teknik pengambilan sampel yang memberikan peluang yang sama bagi setiap unsur (anggota) populasi untuk dipilih menjadi anggota sampel.

Besarnya sampel dalam penelitian ini ditentukan degan rumus slovin sebagai berikut, Sujarweni (2014:66-67) :

$$
n=\frac{N}{1+N e^{2}}
$$

dimana:

$n=$ jumlah elemen / anggota sampel

$\mathrm{N}=$ jumlah elemen /anggota populasi

$\mathrm{E}=$ error level (tingkat kesalahan) (catatan: umumnya digunakan 1 $\%$ atau

$0,01,5 \%$ atau 0,05 , dan 10 $\%$ atau 0,1 ) (catatan dapat dipilih oleh peneliti).

Populasi yang terdapat dalam penelitian ini berjumlah 69 orang dan presisi yang ditetapkan atau tingkat signifikasi 0,05 , maka besarnya sampel pada penelitian ini adalah :

$$
\begin{aligned}
& n=\frac{N}{1+\left(N X e^{2}\right)} \\
& n=\frac{69}{1+\left(69 \cdot 0,1^{2}\right)}=40.82= \\
& \text { dibulatkan menjadi } 41 .
\end{aligned}
$$

Berdasarkan perhitungan diatas sampel yang menjadi responden dalam penelitian ini di sesuaikan menjadi sebanyak 41 orang dari seluruh total pegawai Dinas Tenaga Kerja dan Transmigrasi Banyuasin, hal ini dilakukan untuk mempermudah dalam pengelolaan data dan untuk hasil pengujian yang lebih baik.

\section{2) Teknik Pengumpulan Data $>$ Observasi}

Menurut Sutrisno hadi dalam Sugiyono (2018:145), bahwa observasi merupakan suatu proses yang komplek, suatu proses yang tersusun dari berbagai proses biologis dan psikologis. Dua diantara yang penting adalah proses-proses pengamatan dan ingatan.

Dokumentasi
Dokumentasi adalah tehnik
pengumpulan data yang tidak
langsung ditujukan pada subjek
penelitian, namun melalui dokumen.
Dokumen yang digunakan dapat
berupa buku harian atau catatan
laporan, dan dokumen lainnya.


$>$ Kuesioner (Angket)

Menurut sugiyono (2018:142), Kuesioner merupakan teknik pengumpulan data yang dilakukan dengan cara memberi seperangkat pertanyaan atau peryataan tertulis kepada responden untuk dijawab.

\section{3) Teknik Analisis Data}

a. Uji Instrumen

$>\quad$ Uji Validitas

Menurut Priyatno (2018:21) Uji validitas adalah tingkat di mana suatu istrumen mengukur apa saja yang harus diukur. Validitas berarti sejauh mana ketepatan dan kecermatan suatu intrumen dalam melakukan fungsi ukurnya. Dalam penelitian ini dilakukan uji validitas yang mengunakan metode Corrected item-total correlations

1. Jika Sig $<a=0,05$ maka dianggap instrumen memiliki validitas yang baik.

2. Jika Sig >a =0,05 maka dianggap instrumen tidak memiliki validitas yang baik.

Uji validitas pada penelitian ini menggunakan bantuan komputer program SPSS Versi 23. Dan menentukan $r$ tabel $\mathrm{df}=\mathrm{n}-2$ dengan taraf signifikan $5 \%$.

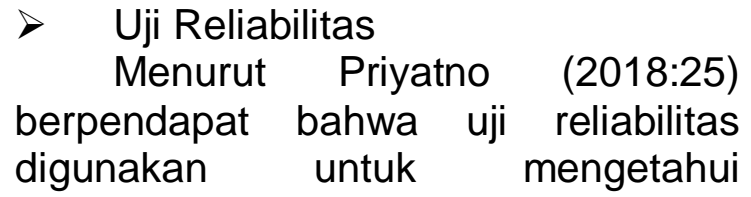
konssistensi alat ukur yang biasanya mengunakan kusioner. Maksudnya apakah alat ukur tersebut akan mendapatkan pengukuran yang tetap konsisten jika pengukuran di ulang kembali .Uji reliabilitas pada penelitian ini mengunakan metode Cronbach Alpha diuji mengunakan bantuan SPSS for windows 23.

1. Cronbach Alpha $>0,60$ reliabelitas.

2. Cronbach Alpha $<0,60$ kurang reliabelitas.

$>\quad$ Uji Asumsi Klasik a) Uji Normalitas

Menurut Priyatno (2018:127), Normalitas data merupakan syarat pokok harus di penuhi dalam analisis parametrik. Normalitas data merupakan hal yang penting karena dengan data yang terdistribusi normal, maka data tersebut dianggap dapat mewakili populasi.

Dalam penelitian ini normalitas data di uji mengunakan uji one sample kolmogorov-smirnov test. Dalam uji one sample kolmogorov-smirnov test, variabel-variabel yang mempunyai asympototic signifinance (2-tailed) diatas tingkat signifikan 0,05 maka diartikan bahwa variabel-variabel tersebut memiliki distribusi normal dan sebaliknya. Pengambilan keputusan normal atau tidaknya data adalah sebagai berikut :

$\checkmark$ Jika Sig <0,05 distribusi data adalah tidak normal.

$\checkmark$ Jika Sig $>0,05$ distribusi data adalah normal.

b) Uji Multikolinieritas

Menurut Priyatno (2018:134) menjelaskan bahwa uji asumsi klasik jenis ini diterapkan untuk menganalisa regresi berganda yang terdiri atas dua atau tiga variabel bebas atau independent variabel. Dimana akan diukur tingkat asosiasi hubungan pengaruh antara variabel bebas tersebut dengan melihat nilai tolernce dan inflation faktor (VIF). Adapun teknik yang digunakan dalam uji multikolinieritas dengan alat bantu mengunakan SPSS for windows 23 pada penelitian ini.

Metode untuk menguji adanya multikolonieritas dapat dilihat dari Variance Inflation Factor (VIF). 
$\checkmark \quad$ Jika VIF $>10$ atau jika tolerance $<\quad 0,01$ tidak terjadi multikolinieritas.

$\checkmark \quad$ Jika VIF $<10$ atau jika tolerance $>0,01$ terjadi multikolinieritas.

c) Uji Heteroskedastisitas

Menurut Priyatno (2018:136) menjelaskan uji heteroskedisitisitas adalah keadaan dimana terjadi ketidaksamaan varian dari residu untuk pengamatan pada model regresi. Salah satu cara untuk mendeteksi ada tidaknya heteroskedasitisitas adalah melihat grafik plot antara nilai prediksi standardized predicted value (ZPRED) dengan residual studentized resiual (SRESID). Deteksi ada tidaknya pola tertentu pada grafik scatterplot antara SRESID dan ZPRED dimana sumbu $Y$ adalah $Y$ yang telah diprediksikan dan sumbu $X$ adalah residualnya $(Y$ prediksi-Y sesungguhnya). Adapun teknik yang digunakan dalam uji heteroskedesitisitas dengan alat bantu mengunakan SPSS for windows 23 pada penelitian ini.

\section{1) Analisis Regresi Berganda}

Menurut Priyatno (2018:107) Analisis ini digunakan untuk menentukan ketepatan prediksi apakah ada hubungan yang kuat antara variabel bebas (X1) kepuasan kerja, dan variabel (X2) beban kerja serta variabel terikat ( $\mathrm{Y})$ Kinerja pegawai, maka dalam penelitian ini regresinya sebagai berikut :

Formula untuk regresi berganda adalah sebagai berikut :

Rumus :

$$
\mathrm{Y}=\mathrm{a}+\mathrm{b}_{1} \mathrm{X}_{1}+\mathrm{b}_{2} \mathrm{X}_{2}+\mathrm{e}
$$

Dimana :

$\mathrm{Y} \quad=$ Kinerja Pegawai

a $\quad=$ Nilai Konstanta

$\mathrm{X}_{1}=$ Kepuasan Kerja

$\mathrm{X}_{2}=$ Beban Kerja

$b_{1} \quad=$ Koefisien regresi $X_{1}$

$b_{2} \quad=$ Koefisien regresi $X_{2}$

$\mathrm{e} \quad=$ Standard error of the estimate

\section{2) Analisis Koefisien Korelasi}

Menurut Priyatno (2018: 59), koefisien korelasi $(\mathrm{R})$ adalah untuk mengetahui kuat atau tidaknya hubungan antara satu variabel dengan variabel yang lain. Dalam analisis korelasi akan di peroleh nilai koefisien korelasi yang menyatakan ukuran keeratan hubungan antara satu variabel dengan variabel lainnya. Berikut ini adalah tabel interpretasi koefisien korelasi.

Tabel Interpretasi Koefisien Korelasi

\begin{tabular}{|c|c|}
\hline Interval Koefisien & Tingkat Hubungan \\
\hline $0,000-0,0199$ & Sangat Rendah \\
\hline $0,200-0,399$ & Rendah \\
\hline $0,400-0,599$ & Sedang \\
\hline $0,600-0,779$ & Kuat \\
\hline $0,800-0,1000$ & Sangat Kuat \\
\hline
\end{tabular}

Sumber : Sugiyono (2018:287)

3) Analisis Koefisien Determinasi

Koefisien determinasi adalah angka yang menyatakan atau digunakan untuk mengetahui koefisien atau koreal yang diberikan sebuah variabel atau lebih $X$ (bebas) terhadap 
variabel Y (terikat) (Siregar, 2013:352). Untuk menghitung koefisien determinasi dengan rumus sebagai berikut:

Rumus : $\mathrm{R}=(\mathrm{r})^{2} \times 100 \%$

Dimana :

$\mathrm{R}=$ Koefisien Determinasi

$r^{2} \quad=$ Kuadrat Koefisien Korelasi

4) Kriteria Pengujian Hipotesis

$>\quad$ Uji $\mathrm{t}$ ( Secara Parsial )

Menurut Sujarweni (2015:161), uji

$t$ adalah pengujian koefisien regresi parsial individual yang digunakan untuk mengetahui apakah variabel independent $(X)$ secara individual mempengaruhi variabel dependent $(Y)$. Dengan menggunakan SPSS for Windows Versi 23.0, dengan langkahlangkah sebagai berikut:

1. Menentukan Hipotesis

Ho: Tidak ada pengaruh kepuasan kerja dan beban kerja secara sendiri-sendiri terhadap kinerja pegawai pada Dinas Tenaga Kerja dan Transmigrasi Banyuasin.

$\mathrm{Ha}$ : ada pengaruh kepuasan kerja dan beban kerja secara sendirisendiri terhadap kinerja pegawai pada Dinas Tenaga Kerja dan Transmigrasi Banyuasin.

2. Menentukan Nilai table dengan tingkat keyakinan 95\%, dengan tingkat kesalahan (a) $5 \%=0,05$ dan derajat kebebasan (df) $=\mathrm{n}-2$. Dilakukan untuk mengetahui ada tidaknya pengaruh antara variabel $\mathrm{X}_{1}, \mathrm{X}_{2}$, dan $\mathrm{Y}$.

3. Menarik kesimpulan

Ho ditolak dan Ha diterima apabila $t_{\text {hitung }} \geq t_{\text {tabel, }}$, Artinya ada pengaruh kepuasan kerja dan beban kerja secara parsial terhadap kinerja pegawai pada Dinas Tenaga Kerja dan Transmigrasi Banyuasin.

Ho diterima dan $\mathrm{Ha}$ ditolak apabila $t_{\text {hitung }}<t_{\text {tabel, }}$ Artinya Tidak ada pengaruh kepuasan kerja dan beban kerja secara parsial terhadap kinerja pegawai pada Dinas Tenaga Kerja dan Transmigrasi Banyuasin.

\section{$>\quad$ Uji F ( Secara Simultan ) \\ Menurut sujarweni (2015: 162),} uji $f$ adalah penguji signifikan persamaan yang digunakan untuk mengetahui seberapa besar pengaruh variabel bebas $(\mathrm{X})$ secara bersamasama terhadap variabel tidak bebas (Y). Dengan menggunakan SPSS for Windows Versi 23.0, dengan langkahlangkah sebagai berikut:

1. Menentukan Hipotesis

Ho : Tidak ada pengaruh kepuasan kerja dan beban kerja secara bersama-sama terhadap kinerja pegawai pada Dinas Tenaga Kerja dan Transmigrasi Banyuasin.

$\mathrm{Ha}$ : ada pengaruh kepuasan kerja dan beban kerja secara bersamasama terhadap kinerja pegawai pada Dinas Tenaga Kerja dan Transmigrasi Banyuasin.

2. Menentukan $F_{\text {tabel }}$ dengan tingkat keyakinan 95\%

tingkat kesalahan (a) 5\% =0,05 dan tingkat kebebasan $(\mathrm{dk})=\mathrm{n}-\mathrm{k}-1$ dilakukan untuk mengetahui ada tidaknya pengaruh antara variabel $\mathrm{X}_{1}, \mathrm{X}_{2}$, dan $\mathrm{Y}$.

3. Menarik kesimpulan

Ho ditolak dan Ha diterima apabila $f_{\text {hitung }}>f_{\text {tabel, }}$, Artinya ada pengaruh kepuasan kerja dan beban kerja terhadap kinerja pegawai pada Dinas Tenaga Kerja dan Transmigrasi Banyuasin.

Ho diterima dan $\mathrm{Ha}$ ditolak apabila $f_{\text {hitung }} \leq f_{\text {tabel}}$, Artinya Tidak ada pengaruh kepuasan kerja dan beban kerja terhadap kinerja pegawai pada Dinas Tenaga Kerja dan Transmigrasi Banyuasin. 
D. HASIL PENELITIAN

1) Uji Instrumen

Uji instrumen terdiri dari, uji validitas dan reliabilitas dengan menggunakan 41 sampel, dimana untuk mengetahui sejauh mana ketepatan dan kecermatan suatu instrumen pengukur dalam melakukan fungsi ukurnya, yaitu agar data diperoleh bisa relevan/sesuai dengan tujuan diadakan pengukuran tersebut.

\section{$>\quad$ Uji Validitas}

Menurut Priyatno (2018:21) Uji validitas adalah tingkat di mana suatu istrumen mengukur apa saja yang harus diukur. Validitas berarti sejauh mana ketepatan dan kecermatan suatu intrumen dalam melakukan fungsi ukurnya. Dalam penelitian ini dilakukan uji validitas yang mengunakan metode Corrected item-total correlations Jika Sig $<a=0,05$ maka dianggap instrumen memiliki validitas yang baik. Jika Sig >a $=0,05$ maka dianggap instrumen tidak memiliki validitas yang baik.

Uji validitas pada penelitian ini menggunakan bantuan komputer program SPSS Versi 23., maka $r$ tabel $\mathrm{df}=\mathrm{n}-2$ dengan taraf signifikan $5 \%$, df $=41-2=39$, maka $r_{\text {tabel }}=0,308$.

Tabel Uji Validitas

\begin{tabular}{|c|c|c|c|c|}
\hline Variabel & $\begin{array}{c}\text { Pertanyaan } \\
\text { (indikator) }\end{array}$ & ritung & $r_{\text {tabel }}(n-2)$ & Keterangan \\
\hline \multirow{10}{*}{$\begin{array}{c}\text { Kinerja Pegawai } \\
(\mathrm{Y})\end{array}$} & Y.P1 & 0,335 & \multirow{10}{*}{0,308} & \multirow{10}{*}{ Valid } \\
\hline & Y.P2 & 0,434 & & \\
\hline & Y.P3 & 0,377 & & \\
\hline & Y.P4 & 0,369 & & \\
\hline & Y.P5 & 0,524 & & \\
\hline & Y.P6 & 0,655 & & \\
\hline & $\begin{array}{l}\text { Y.P7 } \\
\end{array}$ & 0,512 & & \\
\hline & Y.P8 & 0,371 & & \\
\hline & Y.P9 & 0,321 & & \\
\hline & Y.P10 & 0,337 & & \\
\hline \multirow{6}{*}{$\begin{array}{c}\text { Kepuasan Kerja } \\
\qquad\left(\mathrm{X}_{1}\right)\end{array}$} & X1.P1 & 0,374 & \multirow{6}{*}{0,308} & \multirow{6}{*}{ Valid } \\
\hline & X1.P2 & 0,434 & & \\
\hline & X1.P3 & 0,339 & & \\
\hline & X1.P4 & 0,396 & & \\
\hline & X1.P5 & 0,394 & & \\
\hline & X1.P6 & 0,321 & & \\
\hline
\end{tabular}




\begin{tabular}{|c|c|c|c|c|}
\hline & X1.P7 & 0,331 & & \\
\hline & X1.P8 & 0,449 & & \\
\hline & X1.P9 & 0,383 & & \\
\hline & $\mathrm{X} 1 . \mathrm{P} 10$ & 0,379 & & \\
\hline \multirow{6}{*}{$\begin{array}{c}\text { Beben Kerja } \\
\left(\mathrm{X}_{2}\right)\end{array}$} & X2.P1 & 0,425 & \multirow{6}{*}{0,308} & \multirow{6}{*}{ Valid } \\
\hline & X2.P2 & 0,462 & & \\
\hline & X2.P3 & 0,412 & & \\
\hline & X2.P4 & 0,556 & & \\
\hline & X2.P5 & 0,467 & & \\
\hline & X2.P6 & 0,596 & & \\
\hline
\end{tabular}

Sumber : Berdasarkan Perhitungan SPSS, 2019

Berdasarkan uji validitas memperlihatkan nilai ritung setiap indikator variabel kepuasan kerja, beban kerja dan kinerja pegawai lebih besar dibanding nilai $r_{\text {tabel. }}$ dengan demikian indikator atau kuesioner yang digunakan oleh masing-masing variabel pengaruh kepuasan kerja dan beban kerja terhadap kinerja pegawai pada Dinas Tenaga Kerja dan Transmigrasi Banyuasin dinyatakan Valid untuk digunakan sebagai alat ukur variabel, karena keseluruhan indikator yang digunakan memiliki nilai $r_{\text {hitung }}>r_{\text {tabel }}$ atau $\operatorname{Sig}<a=0,05$.

\section{Uji Reliaibilitas}

Menurut Priyatno ( 2018:25) berpendapat bahwa uji reliabilitas digunakan untuk mengetahui konssistensi alat ukur yang biasanya mengunakan kusioner. Maksudnya apakah alat ukur tersebut akan mendapatkan pengukuran yang tetap konsisten jika pengukuran di ulang kembali .Uji reliabilitas pada penelitian ini mengunakan metode Cronbach Alpha diuji mengunakan bantuan SPSS for windows 23.

Cronbach Alpha > 0,60 reliabelitas.

Cronbach Alpha $<0,60$ kurang reliabelitas

Maka hasil pengujian realibilitas untuk setiap variabel, sebagai berikut :

Tabel Uji Reliabilitas

\begin{tabular}{|l|c|c|c|}
\hline \multicolumn{1}{|c|}{ Variabel } & $\begin{array}{c}\text { Cronbach's } \\
\text { Alpha }\end{array}$ & $\begin{array}{c}\text { Standar } \\
\text { Reliabilitas }\end{array}$ & Keterangan \\
\hline Kinerja Pegawai $(\mathrm{Y})$ & 0,658 & 0,60 & Reliabel \\
\hline Kepuasan Kerja $\left(\mathrm{X}_{1}\right)$ & 0,634 & 0,60 & Reliabel \\
\hline Beban Kerja $\left(\mathrm{X}_{2}\right)$ & 0,670 & 0,60 & Reliabel \\
\hline
\end{tabular}

Sumber : Berdasarkan Perhitungan SPSS, 2019 
Berdasarkan uji reliabilitas pada Tabel 3, nilai Cronbach's Alpha semua variabel lebih besar dari 0,60 sehingga dapat disimpulkan indikator atau kuesioner yang digunakan variabel pengaruh kepuasan kerja dan beban kerja terhadap kinerja pegawai pada Dinas Tenaga Kerja dan Transmigrasi Banyuasin semua dikatakan reliabilitas dan dapat dipercaya sebagai alat ukur variabel.

\section{2) Gambaran Umum Jawaban Responden \\ Berdasarkan hasil jawaban} responden melalui kuesioner yang telah disebarkan kepada responden, berikut ini adalah hasil tabulasi jawaban yang diberikan responden atas butiran pertanyaan dari masingmasing variabel :

\section{Kinerja Pegawai $(Y)$}

Tabel Variabel Kinerja Pegawai

\begin{tabular}{|c|l|c|c|c|c|c|}
\hline No & \multicolumn{1}{|c|}{ Pertanyaan } & SS & S & RR & TS & STS \\
\hline 1. & $\begin{array}{l}\text { Atasan selalu memberi } \\
\text { kesempatan pegawainya untuk } \\
\text { mendapatkan jenjang karier } \\
\text { kerjanya }\end{array}$ & $39,0 \%$ & $41,5 \%$ & $19,5 \%$ & $0 \%$ & $0 \%$ \\
\hline 2. & $\begin{array}{l}\text { Atasan selalu bekerja sama } \\
\text { dengan bawahanya }\end{array}$ & $12,2 \%$ & $36,6 \%$ & $26,8 \%$ & $14,6 \%$ & $9,8 \%$ \\
\hline 3. & $\begin{array}{l}\text { Semua pegawai selalu hadir } \\
\text { dalam kegiatan }\end{array}$ & $34,1 \%$ & $43,9 \%$ & $12,2 \%$ & $4,9 \%$ & $4,9 \%$ \\
\hline 4. & $\begin{array}{l}\text { Semua pegawai selalu datang } \\
\text { tepat waktu }\end{array}$ & $39,0 \%$ & $29,3 \%$ & $26,8 \%$ & $2,4 \%$ & $2,4 \%$ \\
\hline 5. & $\begin{array}{l}\text { Saya selalu bersunguh-sunguh } \\
\text { dan teliti dalam menyelesaikan } \\
\text { tugas }\end{array}$ & $41,5 \%$ & $31,7 \%$ & $17,1 \%$ & $7,3 \%$ & $2,4 \%$ \\
\hline 6. & $\begin{array}{l}\text { Saya selalu memperhatikan } \\
\text { petunjuk yang diberikan atasan } \\
\text { dalam menyelesaikan tugas }\end{array}$ & $24,4 \%$ & $36,6 \%$ & $31,7 \%$ & $7,3 \%$ & $0 \%$ \\
\hline 7. & $\begin{array}{l}\text { Produktivitas saya dalam } \\
\text { bekerja sangat dihargai oleh } \\
\text { pimpinan }\end{array}$ & $48,8 \%$ & $26,8 \%$ & $17,1 \%$ & $2,4 \%$ & $4,9 \%$ \\
\hline 8. & $\begin{array}{l}\text { Saya menghasilkan pekerjaan } \\
\text { sesuai dengan standar }\end{array}$ & $24,4 \%$ & $48,8 \%$ & $24,4 \%$ & $0 \%$ & $2,4 \%$ \\
\hline 9. & $\begin{array}{l}\text { Kenyamanan bekerja bersama } \\
\text { rekan-rekan kerja saya }\end{array}$ & $7,3 \%$ & $31,7 \%$ & $22,0 \%$ & $22,0 \%$ & $17,1 \%$ \\
\hline 10 & $\begin{array}{l}\text { Ruang kerja saya membuat } \\
\text { saya nyaman dalam bekerja } \\
\text { karena fasilitas yang memadai }\end{array}$ & $14,6 \%$ & $24,4 \%$ & $29,3 \%$ & $17,1 \%$ & $14,6 \%$ \\
\hline
\end{tabular}

Sumber : Berdasarkan Perhitungan SPSS, 2019

Berdasarkan tabel diatas dapat dijelaskan dijelaskan bahwa diketahui jawaban karyawan dari variabel kinerja pegawai dapat dilihat pada keterangan berikut:

Pertanyaan pertama dimana jawaban pegawai dominan menjawab 
setuju sebesar 41,5\%. Hal ini menunjukkan bahwa atasan selalu memberi kesempatan pegawainya untuk mendapatkan jenjang karier kerjanya hal ini membuat karyawan semangat untuk mengeluarkan kemampuan yang dimilikinya secara maksimal.

Pertanyaan kedua dimana jawaban pegawai dominan menjawab setuju sebesar $36,6 \%$. Hal ini menunjukkan bahwa atasan selalu bekerja sama dengan bawahanya berjalan dengan baik hal ini harus terus dijaga.

Pertanyaan ketiga dimana jawaban pegawai dominan menjawab setuju sebesar 43,9\%. Hal ini menunjukkan bahwa semua pegawai selalu hadir dalam kegiatan yang dilaksanakan Dinas Tenaga Kerja dan Transmigrasi Banyuasin.

Pertanyaan keempat dimana jawaban pegawai dominan menjawab sangat setuju sebesar $39,0 \%$. Hal ini dapat disimpulkan bahwa semua pegawai selalu datang tepat waktu kekantor ini harus dijaga agar karyawan selalu disiplin.

Pertanyaan kelima dimana jawaban pegawai dominan menjawab sangat setuju 41,5\%. Hal ini dapat disimpulkan bahwa saya selalu bersunguh-sunguh dan teliti dalam menyelesaikan tugas hal ini harus dijaga oleh karyawan dan Dinas Tenaga Kerja dan Transmigrasi Banyuasin.
Pertanyaan keenam dimana jawaban pegawai dominan menjawab setuju 36,6\%. Hal ini dapat disimpulkan bahwa pegawai selalu memperhatikan petunjuk yang diberikan atasan dalam menyelesaikan tugas-tugasnya.

Pertanyaan ketujuh dimana jawaban pegawai dominan menjawab sangat setuju 48,8\%. Hal ini dapat disimpulkan bahwa Produktivitas pegawai dalam bekerja sangat dihargai oleh pimpinan.

Pertanyaan kedelapan dimana jawaban pegawai dominan menjawab setuju 48,8\%. Hal ini dapat disimpulkan bahwa pegawai menghasilkan pekerjaan sesuai dengan standar yang telah ditentukan Dinas Tenaga Kerja dan Transmigrasi Banyuasin.

Pertanyaan kesembilan dimana jawaban pegawai dominan menjawab setuju 31,7\%. Hal ini dapat disimpulkan bahwa kenyamanan didalam pegawai bekerja bersama rekan-rekan kerja berjalan dengan baik.

Pertanyaan kesepuluh dimana jawaban pegawai dominan menjawab ragu-ragu $29,3 \%$. Hal ini dapat disimpulkan bahwa ruang kerja para pegawai membuat nyaman dalam bekerja karena fasilitas yang memadai dirasa masih kurang di perhatikan Dinas Tenaga Kerja dan Transmigrasi Banyuasin.

\section{Kepuasan Kerja $\left(\mathbf{X}_{1}\right)$}

Tabel Variabel Kepuasan Kerja

\begin{tabular}{|c|l|c|c|c|c|c|}
\hline No & \multicolumn{1}{|c|}{ Pertanyaan } & SS & S & RR & TS & STS \\
\hline 1. & $\begin{array}{l}\text { Anda ditempatkan sesuai } \\
\text { dengan bidang keahlian yang } \\
\text { anda senangi }\end{array}$ & $26,8 \%$ & $43,9 \%$ & $2,4 \%$ & $4,9 \%$ & $22,0 \%$ \\
\hline 2. & $\begin{array}{l}\text { Pekerjaan yang diberikan sesuai } \\
\text { dengan latar belakang }\end{array}$ & $26,8 \%$ & $31,7 \%$ & $9,8 \%$ & $4,9 \%$ & $26,8 \%$ \\
\hline
\end{tabular}




\begin{tabular}{|c|l|c|c|c|c|c|}
\hline & pendidikan anda & & & & \\
\hline 3. & $\begin{array}{l}\text { Pekerjaan yang selalu saya } \\
\text { kerjakan selesai dengan hasil } \\
\text { yang maksimal }\end{array}$ & $14,6 \%$ & $48,8 \%$ & $2,4 \%$ & $4,9 \%$ & $29,3 \%$ \\
\hline 4. & $\begin{array}{l}\text { Saya merasa nyaman dan betah } \\
\text { ketika berada dikantor }\end{array}$ & $24,4 \%$ & $53,7 \%$ & $4,9 \%$ & $2,4 \%$ & $14,6 \%$ \\
\hline 5. & $\begin{array}{l}\text { Bila ada masalah dalam } \\
\text { pekerjaan, anda mendapatkan } \\
\text { dukungan moril dari sesama } \\
\text { rekan kerja }\end{array}$ & $17,1 \%$ & $39,0 \%$ & $12,2 \%$ & $4,9 \%$ & $26,8 \%$ \\
\hline 6. & $\begin{array}{l}\text { Anda merasa senang dengan } \\
\text { jabatan anda saat ini, karena } \\
\text { sesuai dengan yang anda } \\
\text { harapkan }\end{array}$ & $17,1 \%$ & $39,0 \%$ & $12,2 \%$ & $0 \%$ & $31,7 \%$ \\
\hline 7. & $\begin{array}{l}\text { Saya selalu dapat menanti } \\
\text { waktu kerja yang telah } \\
\text { ditetapkan }\end{array}$ & $26,8 \%$ & $48,8 \%$ & $7,3 \%$ & $0 \%$ & $17,1 \%$ \\
\hline 8. & $\begin{array}{l}\text { Saya } \\
\text { melaksanakan pekerjaan saya } \\
\text { dengan baik sesuai kemampuan } \\
\text { saya }\end{array}$ & $12,2 \%$ & $51,2 \%$ & $7,3 \%$ & $0 \%$ & $29,3 \%$ \\
\hline 9. & $\begin{array}{l}\text { Kesulitan dalam pekerjaan dapat } \\
\text { terpecahkan dengan baik }\end{array}$ & $26,8 \%$ & $46,3 \%$ & $2,4 \%$ & $0 \%$ & $24,4 \%$ \\
\hline 10 & $\begin{array}{l}\text { Kesempatan untuk kenaikan } \\
\text { jabatan }\end{array}$ & $22,0 \%$ & $46,3 \%$ & $7,3 \%$ & $0 \%$ & $24,4 \%$ \\
\hline
\end{tabular}

Sumber : Berdasarkan Perhitungan SPSS, 2019

Berdasarkan tabel diatas dapat dijelaskan dijelaskan bahwa diketahui jawaban karyawan dari variabel kepuasan kerja dapat dilihat pada keterangan berikut:

Pertanyaan pertama dimana jawaban pegawai dominan menjawab setuju sebesar 43,9\%. Hal ini dapat disimpulkan bahwa pegawai ditempatkan sesuai dengan bidang keahlian yang disenanginya.

Pertanyaan kedua dimana jawaban pegawai dominan menjawab setuju sebesar $31,7 \%$. Hal ini dapat disimpulkan bahwa pekerjaan yang diberikan sesuai dengan latar belakang pendidikan para pegawai.

Pertanyaan ketiga dimana jawaban pegawai dominan menjawab setuju sebesar 48,8\%. Hal ini dapat disimpulkan bahwa pekerjaan yang selalu pegawai kerjakan selesai dengan hasil yang maksimal telah dilakukan dengan baik.

Pertanyaan keempat dimana jawaban pegawai dominan menjawab setuju sebesar $53,7 \%$. Hal ini dapat disimpulkan bahwa pegawai merasa nyaman dan betah ketika berada dikantor.

Pertanyaan kelima dimana jawaban pegawai dominan menjawab setuju sebesar 39,0\%. Hal ini dapat disimpulkan bahwa bila ada masalah dalam pekerjaan, pegawai mendapatkan dukungan moril dari sesama rekan kerja telah dilakukan para pegawai dengan baik.

Pertanyaan keenam dimana jawaban pegawai dominan menjawab setuju sebesar 39,0\%. Hal ini dapat disimpulkan bahwa pegawai merasa 
senang dengan jabatannya saat ini, karena sesuai dengan yang diharapkan pegawai.

Pertanyaan ketujuh dimana jawaban pegawai dominan menjawab setuju sebesar 48,8\%. Hal ini dapat disimpulkan bahwa bila ada masalah dalam pekerjaan, pegawai mendapatkan dukungan moril dari sesama rekan kerja talh dilakukan para pegawai dengan baik.

Pertanyaan kedelapan dimana jawaban pegawai dominan menjawab setuju sebesar $51,2 \%$. Hal ini dapat disimpulkan bahwa pegawai selalu dapat melaksanakan pekerjaan dengan baik sesuai kemampuan para pegawai.

Pertanyaan kesembilan dimana jawaban pegawai dominan menjawab setuju sebesar 46,3\%. Hal ini dapat disimpulkan bahwa kesulitan dalam pekerjaan dapat terpecahkan dengan baik oleh para pegawai.

Pertanyaan kesepuluh dimana jawaban pegawai dominan menjawab setuju sebesar 46,3\%. Hal ini dapat disimpulkan bahwa kesempatan untuk kenaikan jabatan terbuka lebar untuk para pegawai.

\section{Beban Kerja $\left(\mathrm{X}_{2}\right)$}

Tabel Variabel Beban Kerja

\begin{tabular}{|c|l|c|c|c|c|c|}
\hline No & \multicolumn{1}{|c|}{ Pertanyaan } & SS & S & RR & TS & STS \\
\hline 1. & $\begin{array}{l}\text { Saya selalu dapat mencapai } \\
\text { target yang ditetapkan }\end{array}$ & $2,4 \%$ & $24,4 \%$ & $19,5 \%$ & $51,2 \%$ & $2,4 \%$ \\
\hline 2. & $\begin{array}{l}\text { Disaat jam istirahat saya masih } \\
\text { menyelesaikan pekerjaan saya }\end{array}$ & $12,2 \%$ & $24,4 \%$ & $17,1 \%$ & $43,9 \%$ & $2,4 \%$ \\
\hline 3enerangan yang ada (sinar \\
3. \\
$\begin{array}{l}\text { matahari dan listrik) diruang } \\
\text { kerja telah sesuai dengan } \\
\text { kebutuhan }\end{array}$ & $4,9 \%$ & $34,1 \%$ & $17,1 \%$ & $39,0 \%$ & $4,9 \%$ \\
\hline 4. & $\begin{array}{l}\text { Fasilitas kerja yang tersedia saat } \\
\text { ini sudah cukup memadai untuk } \\
\text { mendukung aktivitas kerja }\end{array}$ & $14,6 \%$ & $24,4 \%$ & $17,1 \%$ & $41,5 \%$ & $2,4 \%$ \\
\hline 5. & $\begin{array}{l}\text { Standar kualitas kerja yang telah } \\
\text { ditetapkan oleh instansi selama } \\
\text { ini dapat saya capai dengan baik }\end{array}$ & $19,5 \%$ & $22,0 \%$ & $26,8 \%$ & $29,3 \%$ & $2,4 \%$ \\
\hline 6. & $\begin{array}{l}\text { Saya berusaha menghasilkan } \\
\text { kualitas kerja yang baik } \\
\text { dibandingkan dengan rekan } \\
\text { kerja }\end{array}$ & $9,8 \%$ & $26,8 \%$ & $17,1 \%$ & $43,9 \%$ & $2,4 \%$ \\
\hline
\end{tabular}

Sumber : Berdasarkan Perhitungan SPSS, 2019

Berdasarkan tabel diatas dapat dijelaskan dijelaskan bahwa diketahui jawaban karyawan dari variabel beban kerja dapat dilihat pada keterangan berikut:

Pertanyaan pertama dimana jawaban pegawai dominan menjawab tidak setuju $51,2 \%$. Hal ini dapat disimpulkan bahwa pegawai selalu dapat mencapai target yang ditetapkan perusahaan belum berkjalan dengan baik masih banyak pegawai yang belum dapat mencapai target yang ditentukan.

Pertanyaan kedua dimana jawaban pegawai dominan menjawab 
tidak setuju sebesar 43,9\%. Hal ini dapat disimpulkan bahwa Disaat jam istirahat pegawai masih menyelesaikan pekerjaan tidak berjalan baik.

Pertanyaan ketiga dimana jawaban pegawai dominan menjawab tidak setuju sebesar $39,0 \%$. Hal ini dapat disimpulkan bahwa penerangan yang ada (sinar matahari dan listrik) diruang kerja belum sesuai dengan kebutuhan para pegawai.

Pertanyaan keempat dimana jawaban pegawai dominan menjawab tidak setuju sebesar 41,5\%. Hal ini dapat disimpulkan bahwa Fasilitas kerja yang tersedia saat ini sudah cukup memadai untuk mendukung aktivitas kerja tidak sesuai dengan harapan para pegawai.

Pertanyaan kelima dimana jawaban pegawai dominan menjawab tidak setuju sebesar 29,3\%. Hal ini dapat disimpulkan bahwa Standar kualitas kerja yang telah ditetapkan oleh instansi selama ini belum dapat para pegawai capai dengan baik.

Pertanyaan keenam dimana jawaban pegawai dominan menjawab tidak setuju sebesar 43,9\%. Hal ini dapat disimpulkan bahwa pegawai berusaha menghasilkan kualitas kerja yang baik dibandingkan dengan rekan kerja tidak dilakukan dengan baik.

\section{3) Uji Asumsi Klasik \\ $>\quad$ Uji Normalitas}

Menurut Priyatno (2018:127), Normalitas data merupakan syarat pokok harus di penuhi dalam analisis parametrik. Normalitas data merupakan hal yang penting karena dengan data yang terdistribusi normal, maka data tersebut dianggap dapat mewakili populasi.

Dalam penelitian ini normalitas data di uji mengunakan uji one sample kolmogorov-smirnov test. Dalam uji one sample kolmogorov-smirnov test, variabel-variabel yang mempunyai asympototic signifinance (2-tailed) diatas tingkat signifikan 0,05 maka diartikan bahwa variabel-variabel tersebut memiliki distribusi normal dan sebaliknya. Pengambilan keputusan normal atau tidaknya data adalah sebagai berikut :

Jika Sig <0,05 distribusi data adalah tidak normal.

Jika Sig >0,05 distribusi data adalah normal.

Tabel Uji Normalitas

One-Sample Kolmogorov-Smirnov Test

\begin{tabular}{|c|c|c|c|}
\hline & & KEPUASAN KERJA & BEBAN KERJA \\
\hline $\bar{N}$ & & 41 & 41 \\
\hline Normal Parameters ${ }^{a, b}$ & Mean & 3.3634 & 3.0000 \\
\hline Most Extreme & $\begin{array}{l}\text { Std. Deviation } \\
\text { Absolute }\end{array}$ & $\begin{array}{r}.56159 \\
.133\end{array}$ & $\begin{array}{r}.53669 \\
.121\end{array}$ \\
\hline Differences & $\begin{array}{l}\text { Positive } \\
\text { Negative }\end{array}$ & $\begin{array}{r}.133 \\
-.131\end{array}$ & $\begin{array}{r}.121 \\
-.072\end{array}$ \\
\hline Test Statistic & & .133 & .121 \\
\hline Asymp. Sig. (2-tailed) & & $.067^{c}$ & $.138^{c}$ \\
\hline
\end{tabular}

a. Test distribution is Normal.

b. Calculated from data.

c. Lilliefors Significance Correction.

Sumber : Berdasarkan Perhitungan SPSS, 2019 
Berdasarkan tabel diatas, dapat disimpulkan bahwa nilai uji normalitas Kepuasan kerja sebesar 0,067 dan beban kerja sebesar 0,138 artinya semua variabel memiliki nilai diatas 0,05 hal ini menunjukkkan bahwa model regresi layak dipakai dalam penelitian ini karena memenuhi asumsi normalitas.

\section{$>\quad$ Uji Multikolinieritas}

Menurut Priyatno (2018:134) menjelaskan bahwa uji asumsi klasik jenis ini diterapkan untuk menganalisa regresi berganda yang terdiri atas dua atau tiga variabel bebas atau independent variabel. Dimana akan diukur tingkat asosiasi hubungan pengaruh antara variabel bebas tersebut dengan melihat nilai tolernce dan inflation faktor (VIF). Adapun teknik yang digunakan dalam uji multikolinieritas dengan alat bantu mengunakan SPSS for windows 23 pada penelitian ini.

Metode untuk menguji adanya multikolonieritas dapat dilihat dari Variance Inflation Factor (VIF).

Jika VIF $>10$ atau jika tolerance $<0,01$ tidak terjadi multikolinieritas.

Jika VIF $<10$ atau jika tolerance $>0,01$ terjadi multikolinieritas.

Tabel Uji Multikolinieritas

Coefficients $^{a}$

\begin{tabular}{|l|l|r|}
\hline Model & \multicolumn{2}{|c|}{ VIF } \\
\hline 1 & (Constant) & 1.055 \\
\cline { 2 - 3 } & KEPUASAN KERJA & 1.055 \\
\cline { 2 - 3 } & BEBAN KERJA & \\
\hline
\end{tabular}

a. Dependent Variable: KINERJA PEGAWAI

Sumber : Berdasarkan Perhitungan SPSS, 2019

Hasil uji multikolinieritas dilakukan dengan melihat nilai VIF. Hasil analisis menunjukkan bahwa nilai VIF kedua variabel bebas penelitian yaitu 1,055 dan $1,055<10$, artinya hasil ini menyimpulkan bahwa tidak terjadi multikolinieritas pada model regresi.

\section{> Uji Heteroskedastisitas}

Menurut Priyatno (2018:136) menjelaskan uji heteroskedisitisitas adalah keadaan dimana terjadi ketidaksamaan varian dari residu untuk pengamatan pada model regresi. Salah satu cara untuk mendeteksi ada tidaknya heteroskedasitisitas adalah melihat grafik plot antara nilai prediksi standardized predicted value (ZPRED) dengan residual studentized resiual (SRESID) .Deteksi ada tidaknya pola tertentu pada grafik scatterplot antara SRESID dan ZPRED dimana sumbu $Y$ adalah $Y$ yang telah diprediksikan dan sumbu $X$ adalah residualnya $(Y$ prediksi-Y sesungguhnya). Adapun teknik yang digunakan dalam uji heteroskedesitisitas dengan alat bantu mengunakan SPSS for windows 23 pada penelitian ini. 


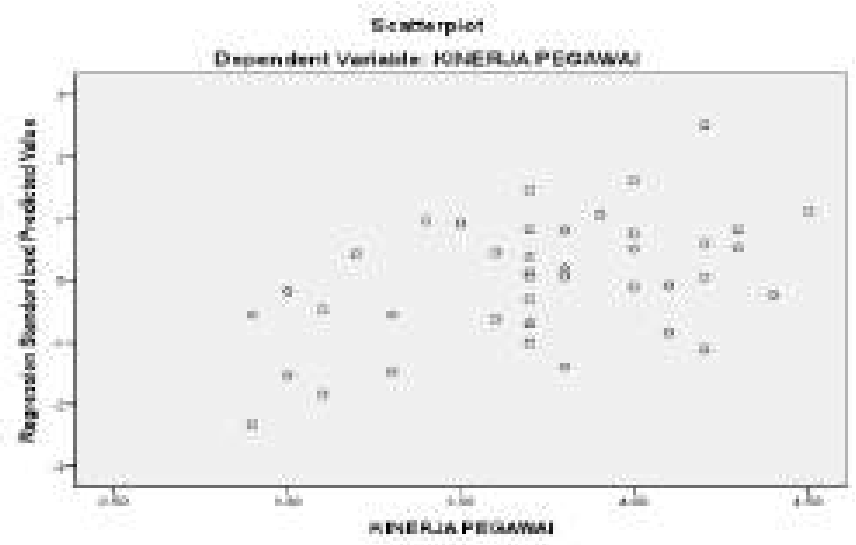

Sumber : Berdasarkan Perhitungan SPSS, 2019

Dari Gambar diatas Scatterplot terlihat bahwa titik-titik menyebar secara acak dan tidak membentuk suatu pola tertentu serta tersebar baik di atas maupun di bawah angka 0 pada sumbu $Y$, sehingga dapat disimpulkan bahwa tidak terjadi heterokedastisitas pada model regresi, sehingga model regresi layak dipakai.

\section{4) Analisis Regresi Linier Berganda \\ Analisis regresi linier berganda} digunakan untuk pengaruh kepuasan kerja dan beban kerja terhadap kinerja pegawai pada Dinas Tenaga Kerja dan Transmigrasi Banyuasin, penulis menggunakan SPSS 23.0 For Windows dengan hasil output sebagai berikut:

Tabel Analisis Regresi Linier Berganda

Coefficients $^{a}$

\begin{tabular}{|ll|r|r|r|}
\hline \multirow{2}{*}{ Model } & \multicolumn{3}{|c|}{ Unstandardized Coefficients } & $\begin{array}{c}\text { Standardized } \\
\text { Coefficients }\end{array}$ \\
\cline { 2 - 5 } & \multicolumn{2}{|c|}{ B } & Std. Error & \multicolumn{1}{c|}{ Beta } \\
\hline 1 & (Constant) & 1.809 & .568 & \\
& KEPUASAN & .318 & .111 & .418 \\
& KERJA & .283 & .116 & .356 \\
\hline
\end{tabular}

a. Dependent Variable: KINERJA PEGAWAI

Sumber : Berdasarkan Perhitungan SPSS, 2019

Pada Tabel 9, diperoleh koefisien konstanta $(\alpha)$ sebesar 1,809 , koefisien untuk variabel kepuasan kerja $\left(\mathrm{X}_{1}\right)$ sebesar 0,318, dan koefisien untuk variabel beban kerja $\left(X_{2}\right)$ sebesar 0,283 . Melalui hasil analisis regresi linier berganda terlihat nilai koefisienkoefisien tersebut dapat dibentuk suatu persamaan regresi sebagai berikut:

$\mathrm{Y}=\mathrm{a}+\mathrm{b} 1 \mathrm{X} 1+\mathrm{b} 2 \mathrm{X} 2+\mathrm{e}$
$Y=1,809+0,318 X_{1}+0,283 X_{2}+e$

Berdasarkan persamaan regresi tersebut, diperoleh nilai konstanta sebesar 1,809 (positif), menunjukkan bahwa seandainya variabel kepuasan kerja dan beban kerja tidak ada, maka kinerja pegawai pada Dinas Tenaga Kerja dan Transmigrasi Banyuasin, hanya memiliki nilai sebesar 1,809.

Nilai koefisien variabel kepuasan kerja, sebesar 0,318 (positif), 
menunjukkan variabel kepuasan kerja berpengaruh terhadap kinerja pegawai pada Dinas Tenaga Kerja dan Transmigrasi Banyuasin. artinya apabila terjadi kenaikkan pada kepuasan kerja pegawai akan menyebabkan kinerja pegawai meningkat, dan sebaliknya apabila kepuasan kerja turun, maka kinerja pegawai akan ikut turun.

Nilai koefisien variabel beban kerja, sebesar 0,283 (positif), menunjukkan variabel beban kerja berpengaruh terhadap kinerja pegawai pada Dinas Tenaga Kerja dan Transmigrasi Banyuasin. artinya apabila beban kerja pegawai baik atau sesuai dengan kemampuan pegawai maka akan menyebabkan kinerja pegawai meningkat, dan sebaliknya apabila beban kerja yang dijalankan pegawai dirasa melebihi kemampuan karyawan, maka kinerja pegawai akan dapat menurun.

\section{5) Analisis Koefisien Korelasi}

Menurut Priyatno (2018: 59), koefisien korelasi $(R)$ adalah untuk mengetahui kuat atau tidaknya hubungan antara satu variabel dengan variabel yang lain. Dalam analisis korelasi akan di peroleh nilai koefisien korelasi yang menyatakan ukuran keeratan hubungan antara satu variabel dengan variabel lainnya.

Tabel Hasil Uji Koefisien Korelasi (R) Model Summary

\begin{tabular}{|l|r|r|r|c|}
\hline Model & $\mathrm{R}$ & $\mathrm{R}$ Square & $\begin{array}{c}\text { Adjusted R } \\
\text { Square }\end{array}$ & $\begin{array}{c}\text { Std. Error of the } \\
\text { Estimate }\end{array}$ \\
\hline 1 & $.483^{\mathrm{a}}$ & .234 & .193 & .38321 \\
\hline
\end{tabular}

a. Predictors: (Constant), BEBAN KERJA, KEPUASAN KERJA

b. Dependent Variable: KINERJA PEGAWAI

Sumber : Berdasarkan Perhitungan SPSS, 2019

Nilai korelasi (R) diperoleh sebesar 0,483 yang berarti bahwa hubungan antara tingkat asosiasi variabel bebas yaitu kepuasan kerja (X1) dan beban kerja (X2) dengan variabel terikat kinerja pegawai pada Dinas Tenaga Kerja dan Transmigrasi Banyuasin (Y) Sedang.

\section{6) Analisis Koefisien Determinasi}

\begin{abstract}
Koefisien determinasi adalah angka yang menyatakan atau digunakan untuk mengetahui koefisien atau koreal yang diberikan sebuah variabel atau lebih $X$ (bebas) terhadap variabel Y (terikat) (Siregar, 2013:352). Untuk menghitung koefisien determinasi dengan rumus sebagai berikut:

Rumus : $R=(r)^{2} \times 100 \%$
\end{abstract}

Tabel Uji Koefisien Determinasi

Model Summary ${ }^{\mathrm{b}}$

\begin{tabular}{|l|r|r|r|c|}
\hline Model & $\mathrm{R}$ & $\mathrm{R}$ Square & $\begin{array}{c}\text { Adjusted R } \\
\text { Square }\end{array}$ & $\begin{array}{c}\text { Std. Error of the } \\
\text { Estimate }\end{array}$ \\
\hline 1 & $.483^{\mathrm{a}}$ & .234 & .193 & .38321 \\
\hline
\end{tabular}
a. Predictors: (Constant), BEBAN KERJA, KEPUASAN KERJA
b. Dependent Variable: KINERJA PEGAWAI
Sumber : Perhitungan Data Primer, SPSS Ver.16 
R Square : $0,234 X 100 \%=23,4 \%$

Perhitungan tersebut memberikan makna bahwa variabel pengaruh kepuasan kerja dan beban kerja terhadap kinerja pegawai pada Dinas Tenaga Kerja dan Transmigrasi Banyuasin, sebesar 23,4\%.Maka dari hasil penelitian ini diketahui adanya pengaruh yang signifikan pada kepuasan kerja dan beban kerja didalam mempengaruhi kinerja pegawai.
Berdasarkan hasil ini pula diketahui adanya sisa peluang nilai pengaruh yang tidak terliputi didalam penelitian ini, yaitu sebesar :

$100 \%-23,4 \%=76,6 \%$

$$
\text { Nilai peluang yang }
$$

dimaksudkan, adalah suatu kemungkinan bahwa masih ada variabel lain yang tidak terliput dalam penelitian ini, yang sifatnya juga mampu mempengaruhi kinerja pegawai.

\section{7) Uji Hipotesis \\ $>\quad \mathrm{Ujit}$}

Tabel Uji t

Coefficients $^{\mathrm{a}}$

\begin{tabular}{|ll|r|r|}
\hline & & \\
Model & & \multicolumn{1}{c|}{ T } & \multicolumn{1}{c|}{ Sig. } \\
\hline 1 & (Constant) & 3.185 & .003 \\
& KEPUASAN KERJA & 2.868 & .007 \\
& BEBAN KERJA & 2.438 & .020 \\
\hline
\end{tabular}

a. Dependent Variable: KINERJA PEGAWAI

Sumber : Berdasarkan Perhitungan SPSS, 2019

Hasil uji t dapat dilihat pada output coefficients dari hasil analisis regresi linier berganda di atas. Apabila t hitung lebih besar dari table serta tingkat signifikannya lebih kecil dari $5 \%(a=$ $5 \%=0,05)$, maka hal ini menunjukan Ho ditolak Ha diterima. Hal ini berarti ada pengaruh signifikan antara variabel independen secara parsial. Pengujian parsial terhadap koefisien regresi secara parsial menggunakan uji t pada tingkat keyakinan 95\% dan tingkat kesalahan dalam analisa (a) $5 \%$ dengan ketentuan degree of freedom (df) $=\mathrm{n}-2$, (df) $=41-2=$ 39 , jadi ttabel sebesar 2,023.
Berdasarkan Tabel 12, dapat dilihat bahwa dari nilai thitung $X 1(2,868)$ $>t_{\text {tabel }}(2,023)$, dengan tingkat sig.t $0,007<0,05$, maka $\mathrm{HO}$ ditolak dan $\mathrm{H}_{\mathrm{a}}$ diterima, artinya ada pengaruh kepuasan kerja secara parsial terhadap kinerja pegawai pada Dinas Tenaga Kerja dan Transmigrasi Banyuasin.

Berdasarkan Tabel 12, dapat dilihat bahwa dari nilai thitung X2 $(2,438)$ $>t_{\text {tabel }}(2,023)$, dengan tingkat sig.t $0,020<0,05$, maka $\mathrm{HO}$ ditolak dan $\mathrm{H}_{\mathrm{a}}$ diterima, artinya ada pengaruh beban kerja secara parsial terhadap kinerja pegawai pada Dinas Tenaga Kerja dan Transmigrasi Banyuasin. 
Tabel Uji F

ANOVA $^{a}$

\begin{tabular}{|c|c|c|c|c|c|}
\hline Model & $\begin{array}{c}\text { Sum of } \\
\text { Squares }\end{array}$ & Df & $\begin{array}{c}\text { Mean } \\
\text { Square }\end{array}$ & $\mathrm{F}$ & Sig. \\
\hline Regression & 1.700 & 2 & .850 & 5.789 & $.006^{b}$ \\
\hline Residual & 5.580 & 38 & 147 & & \\
\hline Total & 7.280 & 40 & & & \\
\hline
\end{tabular}

a. Dependent Variable: KINERJA PEGAWAI

b. Predictors: (Constant), BEBAN KERJA, KEPUASAN KERJA

Sumber : Berdasarkan Perhitungan SPSS, 2019

Uji $F$ ini dimaksudkan untuk menguji variabel-variabel bebas secara simultan/bersama-s ama terhadap variabel terikat, menentukan taraf nyata $(\alpha)$ dan nilai $F_{\text {tabel }}$ pada tingkat keyakinan $95 \%$ dan tingkat kesalahan dalam analisa (a) $5 \%$ dengan ketentuan degree of freedom $(\mathrm{df})=\mathrm{n}-$ $\mathrm{k}-\mathrm{I},(\mathrm{df})=41-2-1=38$, jadi $\mathrm{F}_{\text {tabel }}$ sebesar 3,245.

Berdasarkan Tabel 4.15, dapat dilihat bahwa dari nilai $F_{\text {hitung }}(5,789)>$ $F_{\text {tabel }}(3,245)$, dengan tingkat sig. $F$ $0,006<0,05$, maka $\mathrm{HO}$ ditolak dan $\mathrm{H}_{\mathrm{a}}$ diterima, artinya ada pengaruh kepuasan kerja dan beban kerja secara bersama-sama terhadap kinerja pegawai pada Dinas Tenaga Kerja dan Transmigrasi Banyuasin.

\section{E. PEMBAHASAN}

Berdasarkan hasil analisis yang telah dilakukan dalam pembahasan, diketahui bahwa ada pengaruh positif yang disebabkan variabel pengaruh kepuasan kerja dan beban kerja terhadap kinerja pegawai pada Dinas Tenaga Kerja dan Transmigrasi Banyuasin, yang dibuktikan dengan hasil persamaan regresi: $Y=1,809+$ $0,318 X_{1}+0,283 X_{2}+$ e. Hasil pengujian hipotesis secara simultan pada tingkat kepercayaan 95\%, menunjukkan nilai thitung $X 1 \quad(2,868)>$ $t_{\text {tabel }}(2,023)$, dengan tingkat sig.t 0,007 $<0,05$, artinya ada pengaruh kepuasan kerja secara parsial terhadap kinerja pegawai pada Dinas Tenaga Kerja dan Transmigrasi Banyuasin. Nilai thitung $X 2(2,438)>t_{\text {tabel }}$ $(2,023)$, dengan tingkat sig.t $0,020<$ 0,05 , artinya ada pengaruh beban kerja secara parsial terhadap kinerja pegawai pada Dinas Tenaga Kerja dan Transmigrasi Banyuasin. nilai $F_{\text {hitung }}$ $(5,789)>F_{\text {tabel }}(3,245)$, dengan tingkat sig.F $0,006<0,05$, artinya ada pengaruh kepuasan kerja dan beban kerja secara bersama-sama terhadap kinerja pegawai pada Dinas Tenaga Kerja dan Transmigrasi Banyuasin. Hal ini menunjukkan semua variabel baik variabel $\mathrm{X} 1$ (kepuasan kerja) dan variabel X2 (beban kerja) berpengaruh secara sama-sama atau sendiri-sendiri terhadap variabel $Y$ (kinerja pegawai) pada Dinas Tenaga Kerja dan Transmigrasi Banyuasin.

\section{F. KESIMPULAN DAN SARAN \\ 1. Kesimpulan}

Berdasarkan hasil penelitian dan pembahasan, maka dapat dibuat kesimpulan sebagai berikut:

a) Hasil analisis regresi linier berganda, memperlihatkan pengaruh positif dari masingmasing variabel bebas, yaitu pengaruh kepuasan kerja dan beban kerja terhadap kinerja pegawai pada Dinas Tenaga Kerja dan Transmigrasi 
Banyuasin, yang dibuktikan dengan persamaan regresi: $Y=$ $1,809+0,318 X_{1}+0,283 X_{2}+e$.

b) Hasil pengujian hipotesis secara parsial pada tingkat kepercayaan $95 \%$, menunjukkan nilai $t_{\text {hitung }} \mathrm{X} 1$ $(2,868)>t_{\text {tabel }}(2,023)$, dengan tingkat sig.t 0,007 <0,05, artinya ada pengaruh kepuasan kerja secara parsial terhadap kinerja pegawai pada Dinas Tenaga Kerja dan Transmigrasi Banyuasin. Sedangkan nilai thitung $X 2(2,438)>t_{\text {tabel }}(2,023)$, dengan tingkat sig.t $0,020<0,05$, artinya ada pengaruh beban kerja secara parsial terhadap kinerja pegawai pada Dinas Tenaga Kerja dan Transmigrasi Banyuasin.

c) Hasil pengujian hipotesis secara simultan pada tingkat kepercayaan 95\%, menunjukkan nilai $F_{\text {hitung }}(5,789)>F_{\text {tabel }}(3,245)$, dengan tingkat sig.F $0,006<$ 0,05 , artinya ada pengaruh kepuasan kerja dan beban kerja secara bersama-sama terhadap kinerja pegawai pada Dinas Tenaga Kerja dan Transmigrasi Banyuasin.

d) Nilai uji koefisien determinasi variabel pengaruh kepuasan kerja dan beban kerja terhadap kinerja pegawai pada Dinas Tenaga Kerja dan Transmigrasi Banyuasin, sebesar 23,4\%. Maka dari hasil penelitian ini diketahui adanya pengaruh yang signifikan pada kepuasan kerja dan beban kerja didalam mempengaruhi kinerja pegawai, sedangkan sisa nya $76,6 \%$ dipengaruhi variabel lain yang tidak terliput dalam penelitian ini.

\section{Saran}

Sehubungan dengan kesimpulan diatas dapat diberikan saran-saran sebagai berikut : a) Pegawai disarankan selalu meningkatkan kinerjanya, terutama dengan adanya pemerintahan, kepuasan kerja yang selalu diusahakan dapat diperbaiki oleh pemerintah.

b) Beban kerja diupayakan untuk dapat dicapai oleh pegawai melalui bantuan kerja sama pegawai dengan atasannya dan sesama pegawai.

c) Kinerja pegawai disarankan dapat selalu ditingkatkan melalui pelatihan - pelatihan yang dapat diberikan kepada pegawai.

\section{DAFTAR PUSTAKA}

Arika. 2011. Jurnal artikel analisis beban kerja di tinjau dari faktor usia dengan pendekatan recommended weight limit.

Bella. 2018. Pengaruh Kemampuan dan Pembagian Tugas Terhadap Kinerja Pegawai PT. Kereta Api (PERSERO) Divre III Plaju Palembang..Skripsi. Universitas PGRI Palembang.

\section{Edy Sutrisno, 2019.manajemen sumber daya manusia prenadamedia group.}

Hasibuan, 2017.manajemen sumber daya manusia prenadamedia group.Jakarta

Kadek Ferrania Paramitadewi, 6. 2017. Pengaruh Beban Kerja Dan Kompensasi Terhadap Kinerja Pegawai Sekretariat Pemerintah Daerah Kabupaten Tabanan.

Priyatno, Duwi. 2018. SPSS Panduan Mudah Olah Data Bagi Mahasiswa \& Umum. Yogyakarta : ANDI 
Sahroji Adha, 2019. Pengaruh Kepuasan Kerja Terhadap Kinerja Pegawai Pada Dinas Perindustrian, Perdagangan Dan Esdm Kabupaten Pandeglang.

Santot Iskandar, 2012. Pengaruh beben kerja, motivasi dan kepuasan kerja terhadap kinerja pegawai Bank BJB Cabang Padalarang.

Sugiyono. 2013. Metode Penelitian Manajemen Bandung
Sugiyono. 2018. Metode Penelitian Kuantitatif, Kualitatif dan R\&D. Bandung: ALFABETA

Sujarweni, W, V. 2014. Metode Penelitian . Yogyakarta: PUSTAKA BARU PRES

Sujarweni, W, V. 2015. Metode Penelitian. Yogyakarta : PUSTAKA BARU PRES

Wibowo. 2011. Manajemen kinerja. Jakarta : PT. Raja Grafindo Persada 